\title{
STUDI PEMODELAN DAN PERHITUNGAN TRANSPORT MONTE CARLO DALAM TERAS HTR PEBBLE BED
}

\author{
Zuhair \\ Pusat Teknologi Reaktor dan Keselamatan Nuklir - BATAN
}

\begin{abstract}
Abatrak
Konsep sistem energi VHTR baik yang berbahan bakar pebble (VHTR pebble bed) maupun blok prismatik (VHTR prismatik) menarik perhatian fisikawan reaktor nuklir. Salah satu kelebihan teknologi bahan bakar bola adalah menawarkan terobosan teknologi pengisian bahan bakar tanpa harus menghentikan produksi listrik. Selain itu, partikel bahan bakar pebble dengan kernel uranium oksida $\left(\mathrm{UO}_{2}\right)$ atau uranium oksikarbida (UCO) yang dibalut TRISO dan pelapisan silikon karbida $(\mathrm{SiC})$ dianggap sebagai opsi utama dengan pertimbangan performa tinggi pada burn-up bahan bakar dan temperatur tinggi. Makalah ini mendiskusikan pemodelan dan perhitungan transport Monte Carlo dalam teras HTR pebble bed. HTR pebble bed adalah reaktor berpendingin gas temperatur tinggi dan bermoderator grafit dengan kemampuan kogenerasi. Perhitungan dikerjakan dengan program MCNP5 pada temperatur $1200 \mathrm{~K}$. Pustaka data nuklir energi kontinu ENDF/B-V dan ENDF/B-VI dimanfaatkan untuk melengkapi analisis. Hasil perhitungan secara keseluruhan menunjukkan konsistensi dengan nilai $k_{\text {eff }}$ yang hampir sama untuk pustaka data nuklir yang digunakan. Pustaka ENDF/B-VI (66c) selalu memproduksi $k_{\text {eff }}$ lebih besar dibandingkan ENDF/B-V (50c) maupun ENDF/B-VI (60c) dengan bias kurang

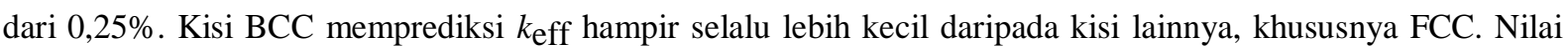

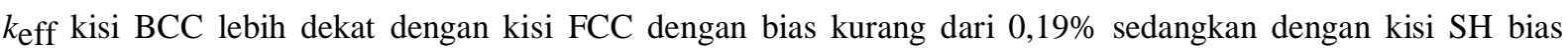
perhitungannya kurang dari $0,22 \%$. Fraksi packing yang sedikit berbeda $(\mathrm{BCC}=61 \%, \mathrm{SH}=60,459 \%)$ tidak

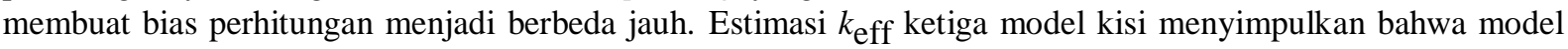
BCC lebih bisa diadopsi dalam perhitungan HTR pebble bed dibandingkan model FCC dan SH. Verifikasi hasil estimasi ini perlu dilakukan dengan simulasi Monte Carlo atau bahkan program deterministik lainnya guna optimisasi perhitungan teras reaktor temperatur tinggi.
\end{abstract}

Kata-kunci: kernel, TRISO, bahan bakar pebble, HTR pebble bed, MCNP5

\begin{abstract}
The VHTR concept of energy system as well pebble fueled VHTR (VHTR pebble bed) as prismatic block fueled VHTR (VHTR prismatic) attracted the attention of a nuclear reactor physicist. One of the pebble fuel technology advantages is to offer technologycal breakthrough of fuel loading without having to stop production of electricity. In addition, pebble fuel particles with a kernel of uranium oxide (UO2) or uranium oxycarbide (UCO) coated by TRISO and coating of silicon carbide $(\mathrm{SiC})$ is assumed as the main option with consideration of high performance on the burn-up fuel and high temperature. This paper discusses Monte Carlo transport modeling and calculation in core of HTR pebble bed. HTR pebble bed is a high temperature gas cooled and graphite moderated reactor with cogeneration capabilities. The calculation was done with MCNP5 code at temperature of $1200 \mathrm{~K}$. The continuous energy nuclear data library ENDF/B-V and ENDF/B-VI were utilized to complete the analysis. The calculation results show consistency with overall $\mathrm{k}_{\mathrm{eff}}$ values which are almost the same for nuclear data libraries used. The ENDF/B-VI library (66c) always produces keff larger than those of ENDF/B-V (50c) and ENDF/B-VI (60c) with a bias of $0.25 \%$. The BCC lattice predicts keff almost always smaller than those of the other lattices, especially FCC lattice. The keff values of BCC lattice are closer to those of FCC lattice with a bias of less than $0.19 \%$, while with SH lattice the calculation bias is less than $0.22 \%$. A slightly different packing fractions $(\mathrm{BCC}=61 \%, \mathrm{SH}=60.459 \%)$ does not to make the calculation bias become much different. The estimated $\mathrm{k}_{\mathrm{eff}}$ of three lattices concludes that BCC model is more able to be adopted in the calculation of HTR pebble bed compared to the FCC and SH model. Verification of estimation results has to be done with Monte Carlo simulation or even other deterministic code for optimization of high temperature reactor core calculation.
\end{abstract}

Keywords: kernel, TRISO, pebble fuel, HTR pebble bed, MCNP5 


\section{Pendahuluan}

Kecenderungan litbang teknologi reaktor dunia saat ini adalah sistem energi reaktor Generasi IV yang dimotori oleh GIF (Generation IV International Forum) ${ }^{[1]}$. GIF telah melakukan kajian terhadap $\sim 100$ tipe reaktor dengan kriteria pokok: kesinambungan (sustainability), keekonomian (economics), keamanan dan keandalan (safety and reliability) serta resistansi proliferasi dan proteksi fisik (proliferation resistance and physical protection). Dari hasil kajian diperoleh enam kandidat konsep reaktor, yaitu GFR (Gas-cooled Fast Reactor) [2], LFR (Lead-cooled Fast Reactor) [3], MSR (Molten Salt Reactor) [4], SFR (Sodium-cooled Fast Reactor)[5], SCWR (Super Critical Water-cooled Reactor)[6], dan VHTR (Very High Temperature Reactor) [7].

Dari keenam konsep reaktor ini, VHTR yang merupakan reaktor berpendingin gas helium dan bermoderator grafit dengan spektrum neutron termal dan temperatur outlet teras melebihi $900^{\circ} \mathrm{C}$, dianggap paling menjanjikan untuk konsep reaktor kogenerasi. Konsep sistem energi VHTR baik yang berbahan-bakar pebble atau bola (VHTR pebble bed) maupun blok prismatik (VHTR prismatik) menarik perhatian fisikawan reaktor nuklir. Salah satu kelebihan teknologi bahan bakar pebble adalah menawarkan terobosan teknologi pengisian bahan bakar tanpa harus menghentikan produksi listrik. Selain itu, partikel bahan bakar bola dengan kernel uranium oksida $\left(\mathrm{UO}_{2}\right)$ atau uranium oksikarbida (UCO) yang dibalut TRISO (TRistructural-ISOtropic) dan pelapisan silikon karbida ( $\mathrm{SiC}$ ) dianggap sebagai opsi utama dengan pertimbangan performa tinggi pada burn-up bahan bakar dan temperatur tinggi.

Dalam beberapa dekade yang lalu pada awal perkembangannya, pemodelan dan perhitungan reaktor temperatur tinggi dilakukan menggunakan metode deterministik. Walaupun hasilnya tidak begitu mengecewakan, namun dalam beberapa kasus, metode deterministik tidak dapat memberikan hasil seperti yang diinginkan. Hal ini disebabkan karena metode deterministik sering menggunakan geometri yang dirata-ratakan atau cell-averaged, sehingga nilai yang diperoleh tidak dapat dibandingkan secara langsung dengan eksperimen. Dalam kasus seperti ini, nilai eksperimen biasanya dikonversi ke dalam cell averaged untuk membanding-kannya dengan nilai-nilai yang dihitung. Bagaimanapun eksperimen tambahan dibutuhkan untuk mendapatkan faktor koreksi. Eksperimen-eksperimen ini akan memasukkan ketidak-tentuan tambahan pada nilai-nilai eksperimen dan membatasi akurasi eksperimental. Secara tidak langsung hal ini memungkinkan eksperimen tambahan akan mengakibatkan kesalahan sistematik yang tidak diharapkan.

Untuk mendapatkan informasi yang tepat tentang karakteristik teras, dibutuhkan pemodelan dan perhitungan yang lebih akurat. Oleh karena itu, sebuah model fisika reaktor 3-D dari teras reaktor temperatur tinggi dikerjakan dengan program transport Monte Carlo MCNP5[8]. Selain memiliki kapabilitas dalam memodelkan geometri reaktor secara detil dan rinci, MCNP5 dapat merepresentasikan efek transport dengan tepat. Penggunaan data tampang lintang neutron energi kontinu dalam MCNP5 juga sangat berarti dalam mengeliminasi kebutuhan mereduksi jumlah kelompok energi tampang lintang multi kelompok seperti yang banyak digunakan oleh metode deterministik. Studi ini mendiskusikan pemodelan dan perhitungan transport Monte Carlo dalam teras HTR pebble bed. Seluruh perhitungan dikerjakan pada temperatur $1200 \mathrm{~K}$. Tiga pustaka data nuklir energi kontinu ENDF/B-V[9] (50c) dan ENDF/BVI[10] (60c dan 66c) dimanfaatkan untuk melengkapi analisis perhitungan.

\section{Deskripsi Bahan Bakar Bola dan Teras HTR Pebble Bed}

HTR pebble bed dikarakterisasi oleh teras keramik penuh dan pendingin helium yang secara neutronik tidak aktif dan tidak 
korosif. Karena karakteristik ini reaktor dapat dioperasikan pada temperatur yang tinggi dan sangat tinggi. HTR pebble bed menggunakan konsep bahan bakar partikel yang ditemukan di USA. Invensi partikel berlapis (coated particles) dengan kualitas yang sangat baik dari resistansi dan retensi produk fisi kemudian menjadi inovasi fundamental dalam bidang teknologi bahan bakar reaktor temperatur tinggi. Partikel berlapis bahan bakar TRISO yang terdispersi dalam matriks grafit membuat reaktor ini secara khusus berbeda dari tipe reaktor lainnya.

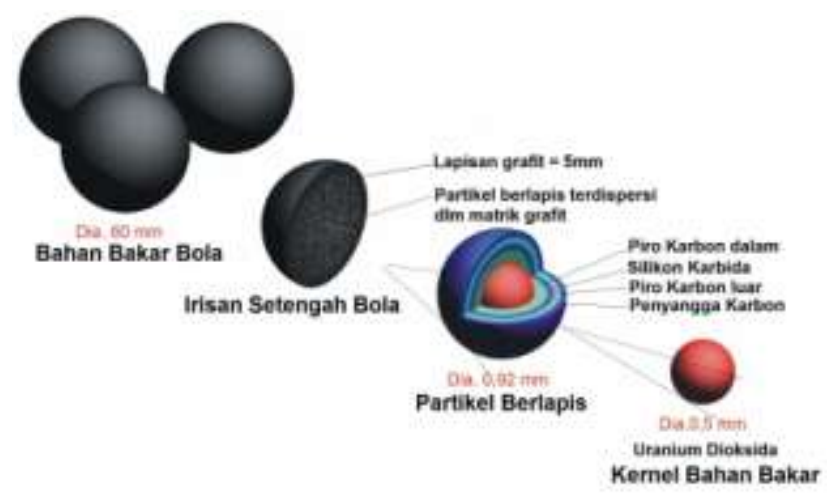

Gambar 1. Skema geometrik bahan bakar HTR pebble bed.

Partikel berlapis TRISO disusun oleh kernel $\mathrm{UO}_{2}$ (pengkayaan $\mathrm{U}^{235} \quad 8,2 \%$ ) dengan diameter $0,05 \mathrm{~cm}$. Partikel ini dikelilingi oleh 4 lapisan yang terdiri atas lapisan penyangga karbon berpori (porous carbon buffer), lapisan piro karbon bagian dalam (inner pyrolitic carbon, IPyC), lapisan silikon karbida (SC) dan lapisan piro karbon bagian luar (outer pyrolitic carbon,
OPyC), yang terdispersi dalam matrik grafit. Sebanyak 15.000 partikel berlapis membentuk bola berdiameter $5 \mathrm{~cm}$ yang dikelilingi oleh shell grafit dengan ketebalan $0,5 \mathrm{~cm}$ dalam sebuah bahan bakar bola. Gambar 1 memperlihatkan skema geometrik bahan bakar bola dan spesifikasi detailnya diberikan dalam Tabel 1.

Tabel 1. Spesifikasi bahan bakar pebble dan partikel berlapis.

\begin{tabular}{lc}
\hline Spesifikasi bahan bakar pebble: & \\
\hline Diameter pebble $(\mathrm{cm})$ & 6,0 \\
\hline Radius zona bahan bakar $(\mathrm{cm})$ & 2,5 \\
\hline Ketebalan cangkang grafit $(\mathrm{cm})$ & 0,5 \\
\hline Densitas cangkang grafit $\left(\mathrm{g} / \mathrm{cm}^{3}\right)$ & 1,75 \\
\hline Impuritas boron alam dalam cangkang grafit $(\mathrm{ppm})$ & 0,5 \\
\hline Jumlah partikel berlapis per pebble & 15.000 \\
\hline Massa bahan bakar per pebble $(\mathrm{g})$ & 10,210 \\
\hline Fraksi kemasan pebble $(\%)$ & 61 \\
\hline Spesifikasi partikel berlapis: & 0,25 \\
\hline Radius kernel bahan bakar $\left(\mathrm{mm}^{3}\right)$ & 10,4 \\
\hline Densitas kernel bahan bakar $\left(\mathrm{g} / \mathrm{cm}^{3}\right)$ & 1 \\
\hline Impuritas boron alam dalam kernel $(\mathrm{ppm})$ & 1,75 \\
\hline Densitas matriks grafit $\left(\mathrm{g} / \mathrm{cm}^{3}\right)$ & 0,5 \\
\hline Impuritas boron alam dalam matriks grafit $(\mathrm{ppm})$ & $\mathrm{C} / \mathrm{C} / \mathrm{SiC} / \mathrm{C}$ \\
\hline Material coating & $0,09 / 0,04 / 0,035 / 0,04$ \\
\hline Ketebalan coating $\left(\mathrm{mm}^{3}\right)$ & $1,05 / 1,9 / 3,18 / 1,9$ \\
\hline Densitas coating $\left(\mathrm{g} / \mathrm{cm}^{3}\right)$ & 9,043 \\
\hline Fraksi kemasan partikel berlapis $(\%)$ & \\
\hline
\end{tabular}


Tabel 2. Parameter reaktor dan spesifikasi teras HTR pebble bed.

\begin{tabular}{lc}
\hline Parameter reaktor: & \\
\hline Daya $(\mathrm{MW})$ & 200 \\
\hline Volume teras $\left(\mathrm{m}^{3}\right)$ & 66,657 \\
\hline Temperatur masuk teras $\left({ }^{\circ} \mathrm{C}\right)$ & 550 \\
\hline Temperatur keluar teras $\left({ }^{\circ} \mathrm{C}\right)$ & 950 \\
\hline Tekanan He $(\mathrm{MPa})$ & 7 \\
\hline Aliran massa pendingin $(\mathrm{kg} / \mathrm{s})$ & 120 \\
\hline Densitas pendingin He pada $273,16 \mathrm{~K} ; 10^{5} \mathrm{~Pa}\left(\mathrm{~g} / \mathrm{cm}^{3}\right)$ & $1,78 \times 10^{-4}$ \\
\hline Spesifikasi teras: & 9,43 \\
\hline Tinggi teras $(\mathrm{m})$ & 1,5 \\
\hline Radius teras $(\mathrm{m})$ & 5.394 \\
\hline Jumlah pebble per m ${ }^{3}$ & 359.519 \\
\hline Jumlah pebble dalam teras & 61 \\
\hline Fraksi kemasan pebble dalam teras $(\%)$ & 2 \\
\hline Impuritas boron alam dalam struktur grafit $(\mathrm{ppm})$ & \\
\hline
\end{tabular}

Kernel $\mathrm{UO}_{2}$ memiliki pengkayaan uranium ${ }^{235} \mathrm{U} /\left({ }^{235} \mathrm{U}_{+}{ }^{238} \mathrm{U}\right)$ sebesar $8,2 \%$. Bahan bakar pebble ditempatkan dalam teras reaktor berdiameter $300 \mathrm{~cm}$ dan tinggi 943 $\mathrm{cm}$. Dengan densitas daya $3 \mathrm{~W} / \mathrm{cm}^{3}$, teras reaktor dapat mencapai daya $200 \mathrm{MW}$. Manajemen bahan bakar reaktor dimulai dengan memasukkan bahan bakar pebble ke dalam teras reaktor dari atas, dan mengeluarkan bahan bakar bekas yang telah digunakan dalam kurun waktu operasi reaktor dari bawah. Inspeksi untuk menentukan bahan bakar pebble yang belum mencapai burn-up yang diinginkan dilakukan untuk menempatkannya kembali ke dalam reaktor. Parameter reaktor dan spesifikasi teras HTR pebble bed diberikan dalam Tabel 2.

\section{Pemodelan dan Perhitungan MCNP5}

Model perhitungan MCNP5 diawali dengan memodelkan partikel berlapis TRISO dalam matriks grafit dengan kisi kubik sederhana (simple cubic) dimana kernel bahan bakar ditempatkan di pusat kisi. Pisahan (pitch) kisi (p) sebesar $0,163429 \mathrm{~cm}$ diperoleh dari hubungan $p=r$ $\times \sqrt[3]{\frac{4 \pi}{3 f}}$ dengan fraksi kemasan (packing fraction, $f)=9,043 \%$ dan $r=0,0455 \mathrm{~cm}$. Gambar 2 memperlihatkan model kisi kubik partikel berlapis TRISO. Kisi kubik sederhana dibentuk dengan model heterogen enam zona yang melukiskan partikel berlapis TRISO dan matriks grafit secara eksplisit. Kisi ini disebut universe-1.

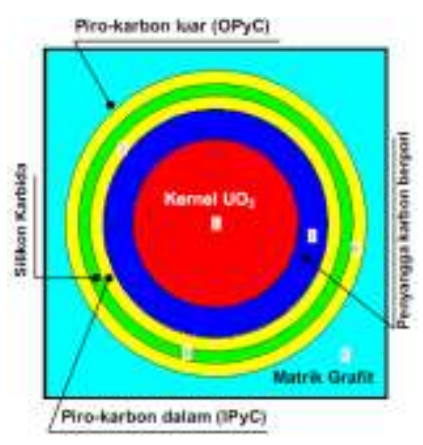

Gambar 2. Model kisi kubik partikel berlapis TRISO. 
Untuk memodelkan bahan bakar pebble, sebanyak 15.000 partikel berlapis TRISO diekspansi ke dalam zona bahan bakar pebble (radius 2,5 $\mathrm{cm}$ ) dengan cara membuat struktur berulang pada kisi kubik partikel berlapis TRISO seperti diperlihatkan dalam Gambar 3. Kisi pebble ini disebut universe-2. Universe-1 dan universe2 digenerasi oleh permukaan-permukaan yang didefinisikan dalam MCNP5.

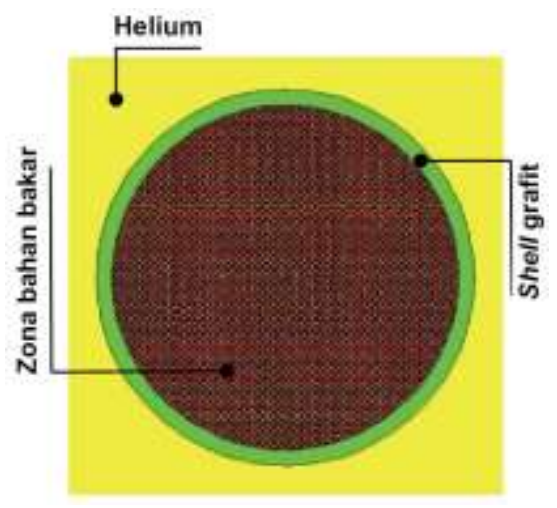

Gambar 3. Model MCNP5 bahan bakar pebble.

Teras reaktor dengan diameter $300 \mathrm{~cm}$ dan tinggi $943 \mathrm{~cm}$ memuat 359.519 bahan bakar pebble yang tersebar secara acak. Sulit sekali mendeskripsikan secara pasti ciri atau karakteristik dari keacakan bahan bakar pebble di dalam teras reaktor. Karena itu model teras digenerasi dengan struktur berulang dari kisi BCC (body-centered cubic), FCC (face-centered cubic) dan SH (simple hexagonal) dimana kisi ini diekspansi untuk menempati keseluruhan volume teras.

Kisi BCC dan FCC pada dasarnya merepresentasikan kubus yang dikarakterisasi oleh fraksi kemasan $61 \%$ sedangkan kisi $\mathrm{SH}$ merepresentasikan prisma dengan alas heksagon yang dikarakterisasi oleh fraksi kemasan maksimum 60,459\%. Fraksi kemasan ini secara tipikal dijumpai di HTR pebble bed karena secara eksperimental telah dibuktikan menggambarkan distribusi stokastik dari bola dalam teras reaktor yang paling dekat dengan geometri nyata. Kisi BCC memuat 2 bahan bakar pebble yang terdiri atas 1 bahan bakar pebble ditempatkan di pusat kisi dan 1 pebble di delapan sudut kisinya yang masing-masing diisi oleh $1 / 8$ bagian dari bahan bakar pebble.

Hampir serupa dengan kisi BCC, kisi FCC dibentuk dengan menghilangkan 1 pebble di pusat kisi dan menggantikannya dengan 3 pebble di enam titik pusat diagonal kisi yang masing-masing diisi oleh $1 / 2$ bagian dari bahan bakar pebble ditambah 1 pebble di delapan sudut kisinya yang masingmasing diisi oleh 1/8 bagian dari bahan bakar pebble. Kisi $\mathrm{SH}$ memuat 1 bahan bakar pebble yang ditempatkan di pusat kisi. Tabel 3 memperlihatkan model kisi yang digunakan dalam perhitungan dan ukuran pisahan (pitch) kisi untuk radius bahan bakar pebble $(\mathrm{R})=3 \mathrm{~cm}$.

Tabel 3. Model kisi dengan jumlah pebble dan pisahan kisi.

\begin{tabular}{cccc}
\hline $\begin{array}{c}\text { Model } \\
\text { kisi }\end{array}$ & $\begin{array}{c}\text { Jumlah pebble } \\
\text { per kisi }\end{array}$ & $\begin{array}{c}\text { Fraksi kemasan } \\
(\%)\end{array}$ & $\begin{array}{c}\text { Pisahan kisi } \\
(\mathrm{cm})\end{array}$ \\
\hline BCC & 2 & 61 & 7,185259 \\
FCC & 4 & 61 & 9,052859 \\
SH & 1 & 60,459 & 6 \\
\hline
\end{tabular}


Densitas atom kernel bahan bakar diberikan dalam Tabel 4 sedangkan densitas atom lapisan kernel, matriks bahan bakar dan cangkang (shell) grafit untuk pebble serta pendingin $\mathrm{He}$ yang digunakan dalam perhitungan diberikan dalam Tabel 5.

Tabel 4. Densitas atom kernel bahan bakar.

\begin{tabular}{ccc}
\hline Kernel & Nuklida & Densitas atom (atom/barn-cm) \\
\hline & ${ }^{238} \mathrm{U}$ & $2,12877 \times 10^{-2}$ \\
\cline { 2 - 3 } $\mathrm{UO}_{2}$ & ${ }^{235_{\mathrm{U}}}$ & $1,92585 \times 10^{-3}$ \\
\cline { 2 - 3 } & $\mathrm{O}$ & $4,64272 \times 10^{-2}$ \\
\cline { 2 - 3 } & ${ }^{10} \mathrm{~B}$ & $1,14694 \times 10^{-7}$ \\
\cline { 2 - 3 } & ${ }^{11_{\mathrm{B}}}$ & $4,64570 \times 10^{-7}$ \\
\hline
\end{tabular}

Tabel 5. Densitas atom lapisan kernel matriks grafit, cangkang grafit dan pendingin.

\begin{tabular}{|c|c|c|c|c|c|}
\hline Material & Nuklida & $\begin{array}{l}\text { Densitas atom } \\
\text { (atom/barn-cm) }\end{array}$ & Material & Nuklida & $\begin{array}{l}\text { Densitas atom } \\
\text { (atom/barn-cm) }\end{array}$ \\
\hline $\begin{array}{l}\text { Penyangga } \\
\text { karbon berpori }\end{array}$ & $\mathrm{C}$ & $5,26449 \times 10^{-2}$ & \multirow{3}{*}{$\begin{array}{l}\text { Matriks } \\
\text { grafit/ } \\
\text { cangkang } \\
\text { grafit }\end{array}$} & $\mathrm{C}$ & $8,77414 \times 10^{-2}$ \\
\hline IPyC/OPyC & $\mathrm{C}$ & $9,52621 \times 10^{-2}$ & & $10_{B}$ & $9,64977 \times 10^{-9}$ \\
\hline \multirow[t]{2}{*}{$\mathrm{SiC}$} & $\mathrm{Si}$ & $4,77240 \times 10^{-2}$ & & $11_{B}$ & $3,90864 \times 10^{-8}$ \\
\hline & $\mathrm{C}$ & $4,77240 \times 10^{-2}$ & \multirow{3}{*}{$\begin{array}{c}\text { Cangkang } \\
\text { grafit }\end{array}$} & $\mathrm{C}$ & $8,77414 \times 10^{-2}$ \\
\hline \multirow[t]{2}{*}{ Pendingin $\mathrm{He}$} & $3_{\mathrm{He}}$ & $3,71220 \times 10^{-11}$ & & $10_{B}$ & $9,64977 \times 10^{-9}$ \\
\hline & ${ }^{4} \mathrm{He}$ & $2,65156 \times 10^{-5}$ & & ${ }^{11} \mathrm{~B}$ & $3,90864 \times 10^{-8}$ \\
\hline
\end{tabular}

Diagram skematik model perhitungan teras HTR pebble bed diperlihatkan dalam Gambar 4 dimana nomor material struktur diindikasikan untuk setiap daerah (region) yang komposisi dan densitas atom materialnya diberikan dalam Tabel 6. Model reaktor dibentuk dari array kisi BCC, FCC dan SH. Opsi LATTICE dan FILL digunakan tiga kali dalam perhitungan ini. Efek absorpsi dari impuritas dispesifikasikan dalam bentuk kandungan boron natural (ppm) yang ekivalen dengan massa. Nilai yang digunakan adalah tipikal untuk teras HTR pebble bed.

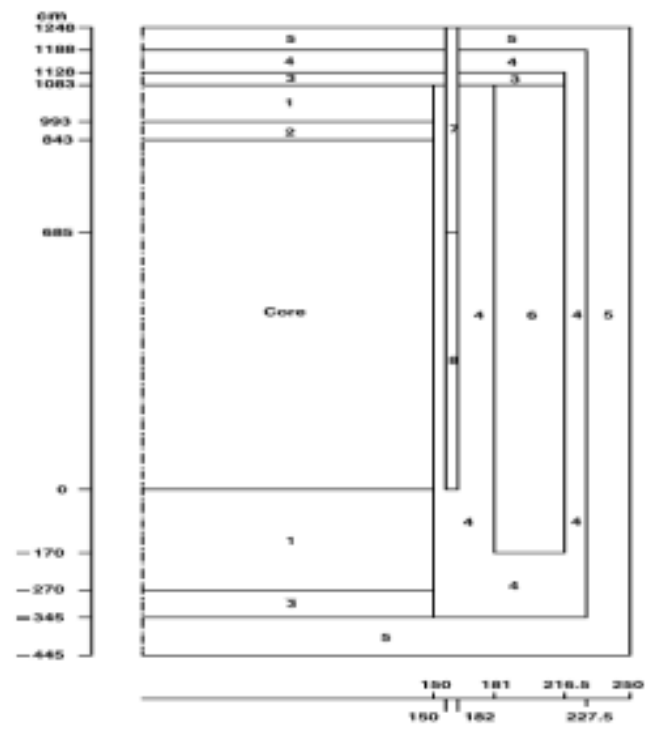

Gambar 4. Model teras HTR pebble bed. 
Tabel 6. Komposisi dan densitas atom material struktur HTR pebble bed.

\begin{tabular}{cccccc}
\hline No. & Material & Densitas & \multicolumn{3}{c}{ Densitas atom (atom/barn-cm) } \\
\cline { 4 - 6 } Daerah & struktur & $\left(\mathrm{g} / \mathrm{cm}^{3}\right)$ & $\mathrm{C}$ & $1{ }_{\mathrm{B}}$ & $1{ }_{\mathrm{B}}$ \\
\hline 1 & Reflektor 1 & 1,53901 & $7,72000 \times 10^{-2}$ & $3,39617 \times 10^{-8}$ & $1,37562 \times 10^{-7}$ \\
\hline 2 & Void & - & $4 \mathrm{He}$ & $1,00000 \times 10^{-11}$ & \\
\hline 3 & Void + grafit & 0,039871 & $2,00000 \times 10^{-3}$ & $8,79837 \times 10^{-10}$ & $3,56378 \times 10^{-9}$ \\
\hline 4 & Reflektor 2 & 1,80016 & $9,03000 \times 10^{-2}$ & $3,97246 \times 10^{-8}$ & $1,60905 \times 10^{-7}$ \\
\hline 5 & $\begin{array}{c}\text { Lapisan karbon di } \\
\text { sekeliling sistem }\end{array}$ & 1,70049 & $8,53000 \times 10^{-3}$ & $3,75250 \times 10^{-8}$ & $1,51995 \times 10^{-7}$ \\
\hline 6 & $\begin{array}{c}\text { Reflektor + kanal } \\
\text { pendingin }\end{array}$ & 1,39946 & $7,02000 \times 10^{-2}$ & $3,08823 \times 10^{-8}$ & $1,25089 \times 10^{-7}$ \\
\hline 7 & $\begin{array}{c}\text { Reflektor + batang } \\
\text { kendali }\end{array}$ & 0,699731 & $3,51000 \times 10^{-2}$ & $1,54411 \times 10^{-8}$ & $6,25444 \times 10^{-8}$ \\
\hline 8 & Reflektor 3 & 0,699731 & $3,51000 \times 10^{-2}$ & $1,54411 \times 10^{-8}$ & $6,25444 \times 10^{-8}$ \\
\hline
\end{tabular}

\section{Hasil Perhitungan dan Analisis}

Perhitungan MCNP5 dikerjakan berdasarkan prinsip keseimbangan neutron. Jumlah neutron dalam setiap generasi dihitung dan komparasi dibuat dengan jumlah neutron dalam generasi berikutnya. Jejak seluruh mekanisme yang memungkinkan neutron lahir dari reaksi fisi, hamburan dan tangkapan serta hilang karena absorpsi dan keluar dari sistem dicatat dan disimulasikan dengan teknik sampling. Faktor multiplikasi dihitung untuk setiap siklus yang diberikan. Setiap neutron fisi digenerasi secara acak dalam lokasi-lokasi dimana material fisil berada.

Seluruh perhitungan dilakukan dengan opsi tipikal KCODE dan KSRC pada temperatur $1200 \mathrm{~K}$ yang dipertimbangkan dengan memasukkan opsi TMP sebagai $k \mathrm{~T}$ dalam satuan energi $\mathrm{MeV}$ mengikuti hubungan $8,617 \times 10^{-11} \times \mathrm{T}$. Setiap siklus KCODE terdiri atas 10.000 neutron dimana jumlah eksaknya bervariasi dari siklus ke siklus, dimulai dari titik sumber fisi yang ditentukan dalam siklus sebelumnya. Hasil perhitungan didasarkan pada 300 siklus total dengan 50 siklus pertama di-skip sebelum tally dimulai untuk memastikan bahwa distribusi sumber sudah stabil. Sumber fisi awal diletakkan dalam pusat sel kisi kubik. Data hamburan termal $\mathrm{S}(\alpha, \beta)$ dengan spesifikasi grph.01t diaplikasikan untuk memodelkan interaksi neutron dengan grafit pada energi di bawah $\sim 4 \mathrm{eV}$. Kondisi batas vakum dikenakan pada semua permukaan luar sistem perangkat setelah memasukkan material dan sifat-sifat lain seperti importance neutron ke dalam setiap sel yang didefinisikan.

Hasil perhitungan faktor multiplikasi efektif ( $k_{\mathrm{eff}}$ ) HTR pebble bed diperlihatkan dalam Tabel 7. Dari Tabel 7 dapat diamati bahwa secara keseluruhan perhitungan MCNP5 menunjukkan konsistensi dengan nilai $k_{\text {eff }}$ yang hampir sama untuk pustaka data nuklir yang digunakan. Pustaka ENDF/B-VI (66c) selalu memproduksi $k_{\text {eff }}$ lebih besar dibandingkan ENDF/B-V (50c) maupun ENDF/B-VI (60c) namun dengan bias kurang dari $0,25 \%$. Dari Tabel 7 dapat diamati pula bahwa untuk seluruh perhitungan, kisi BCC memprediksi $k_{\text {eff }}$ hampir selalu lebih kecil daripada kisi lainnya, khususnya kisi FCC. Nilai $k_{\text {eff }}$ kisi BCC lebih dekat dengan kisi FCC dengan bias kurang dari 0,19\% sedangkan dengan kisi SH bias perhitungannya kurang dari $0,22 \%$. Fraksi packing yang sedikit berbeda $(\mathrm{BCC}=61 \%, \mathrm{SH}=60,459 \%)$ tidak membuat bias perhitungan menjadi berbeda jauh. 
Tabel 7. Hasil perhitungan faktor multiplikasi efektif ( $k_{\text {eff }}$ ) HTR pebble bed.

\begin{tabular}{cccc}
\hline Model kisi & \multicolumn{3}{c}{ Faktor multiplikasi efektif $\left(k_{\text {eff }}\right)$} \\
\cline { 2 - 4 } & ENDF/B-V (50c) & ENDF/B-VI (60c) & ENDF/B-VI (66c) \\
\hline BCC & $1,35799 \pm 0,00047$ & $1,35890 \pm 0,00050$ & $1,35984 \pm 0,00049$ \\
& $(1,00000) \dagger$ & $(1,00000) \dagger$ & $(1,00000) \dagger$ \\
& $(0,99864)$ & $(0,99931)$ & $(1,00000) \dagger \dagger$ \\
\hline FCC & $1,35913 \pm 0,00047$ & $1,35902 \pm 0,00047$ & $1,36249 \pm 0,00052$ \\
& $(1,00084)$ & $(1,00009)$ & $(1,00195)$ \\
& $(0,997534)$ & $(0,997453)$ & $(1,00000) \dagger \dagger$ \\
\hline SH & $1,35500 \pm 0,00047$ & $1,35741 \pm 0,00054$ & $1,36017 \pm 0,00051$ \\
& $(0,99780)$ & $(0,99890)$ & $(1,00024)$ \\
& $(0,99620)$ & $(0,99797)$ & $(1,00000) \dagger \dagger$ \\
\hline
\end{tabular}

$\uparrow$ Perhitungan model kisi BCC dinormalisasi menjadi satu.

$\dagger \dagger$ Perhitungan ENDF/B-VI (66c) dinormalisasi menjadi satu.

Kemasan bola dalam teras HTR pebble bed diekspektasi mendekati kisi HCP namun ketiga kisi menjadi pilihan yang dapat dipertimbangkan, khususnya bila teras hanya dimuati oleh bahan bakar pebble. Bila teras reaktor dimuati oleh bahan bakar pebble dan moderator pebble, kisi FCC tidak dapat dipertimbangkan. Seluruh bola yang dikandung dalam kisi FCC diposisikan di sepanjang batas datar dari sel satuan sehingga sulit memodelkan susunan yang memungkinkan dari bahan bakar pebble dan moderator pebble karena bola-bola yang berdekatan saling tumpang tindih secara tidak konsisten. Kisi SH juga tidak dapat dipertimbangkan karena selain hanya terdiri dari satu bola, kisi SH tidak menyediakan ukuran kemasan yang tepat dan secara tipikal dijumpai di reaktor temperatur tinggi berbahan bakar bola. Dari hasil estimasi

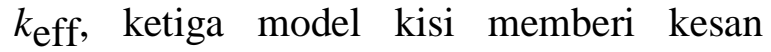
model BCC lebih bisa diadopsi dalam perhitungan dibandingkan model FCC dan $\mathrm{SH}$.

\section{Kesimpulan}

Studi pemodelan dan perhitungan transport Monte Carlo dalam teras HTR pebble bed telah dilakukan dengan program MCNP5 pada temperatur $1200 \mathrm{~K}$. Pustaka data nuklir energi kontinu ENDF/B-V dan ENDF/B-VI dimanfaatkan untuk melengkapi analisis. Hasil perhitungan secara keseluruhan menunjukkan konsistensi dengan nilai $k_{\text {eff }}$ yang hampir sama untuk pustaka data nuklir yang digunakan. Pustaka
ENDF/B-VI (66c) selalu memproduksi $k_{\text {eff }}$ lebih besar dibandingkan ENDF/B-V (50c) maupun ENDF/B-VI (60c) dengan bias kurang dari $0,25 \%$.

Kisi BCC memprediksi $k_{\text {eff }}$ hampir selalu lebih kecil daripada kisi lainnya, khususnya kisi FCC. Nilai $k_{\text {eff }}$ kisi BCC lebih dekat dengan kisi FCC dengan bias kurang dari $0,19 \%$ sedangkan dengan kisi SH bias perhitungannya kurang dari $0,22 \%$. Fraksi packing yang sedikit berbeda $(\mathrm{BCC}=$ $61 \%, \mathrm{SH}=60,459 \%$ ) tidak membuat bias perhitungan menjadi berbeda jauh.

Estimasi $k_{\text {eff }}$ ketiga model kisi menyimpulkan bahwa model BCC lebih bisa diadopsi dalam perhitungan HTR pebble bed dibandingkan model FCC dan SH. Verifikasi hasil estimasi ini perlu dilakukan dengan simulasi Monte Carlo atau bahkan program deterministik lainnya guna optimisasi perhitungan teras reaktor temperatur tinggi.

\section{Daftar Pustaka}

[1]. R.G. Bennett, "An Overview of Generation IV Strategy and Outlook". Proceedings of GIF Symposium, Paris, France, 9-10 September 2009.

[2]. P. Anzieu, R. Stainsby, and K. Mikityuk, "Gas-cooled Fast Reactor (GFR): Overview and Perspectives", Proceedings of GIF Symposium, Paris, France, 9-10 September 2009.

[3]. L. Cinotti, C.F. Smith, and H. Sekimoto, "Lead-cooled Fast Reactor (GLFR): 
Overview and Perspectives", Proceedings of GIF Symposium, Paris, France, 9-10 September 2009.

[4]. C. Renault, M. Hron, R. Konings, and D.E. Holcomb, "The Molten Salt Reactor (MSR) in Generation IV: Overview and Perspectives", Proceedings of GIF Symposium, Paris, France, 9-10 September 2009.

[5]. M. Ichimiya, B.P. Singh, J. Rouault, D. Hahn, J.P. Glatz, and H. Yang, "Overview of R\&D Activities for the Development of A Generation IV Sodium-cooled Fast Reactor (SFR)", Proceedings of GIF Symposium, Paris, France, 9-10 September 2009.

[6]. H. Khartabil, "Super-Critical Water Reactor (SCWR): Overview and Perspectives", Proceedings of GIF
Symposium, Paris, France, 9-10 September 2009.

[7]. F. Carré, P. Yvon, W.J. Lee, Y. Dong, Y. Tachibana, and D. Petti, "VHTR Ongoing International Projects", Proceedings of GIF Symposium, Paris, France, 9-10 September 2009.

[8]. F.B. Brown, et al., "MCNP - General Monte Carlo N-Particle Transport Code, Version 5“, LA-UR-03-1987, 24 April 2003. [9]. Radiation Shielding Center, "DLC105/MCNPDAT: Standard Neutron Cross Section Data Library Derived from ENDF/B-V for MCNP Version 4", 1994.

[10]. J.S. Hendricks, S.C. Frankle, and J.D. Court, “ENDF/B-VI Data for MCNP”, Los Alamos National Laboratory Report, LA12891, 1994. 